\title{
A Novel Monoclonal Antibody Against Canine Monocytes/Macrophages
}

\author{
PAULO HENRIQUE PALIS AGUIAR,,${ }^{1,2}$ ROBERTO ROBSON BORGES DOS SANTOS, ${ }^{2}$ \\ DANIELA FARIAS LARANGEIRA, ${ }^{2}$ MARTA ALMEIDA DOS SANTOS, ${ }^{1}$ \\ STELLA MARIA BARROUIN-MELO, ${ }^{1,2}$ TÂNIA MARIA CORREIA SILVA, ${ }^{1}$ JOSÉ O. MENGEL, ${ }^{1}$ \\ WASHINGTON LUIS CONRADO DOS SANTOS, ${ }^{1,3}$ and LAIN PONTES-DE-CARVALHO ${ }^{1,3}$
}

\begin{abstract}
The production and partial characterization of a monoclonal antibody, the $\operatorname{IgG}_{1} \mathrm{IH}_{1}$, which recognizes an antigen distributed in canine monocytes/macrophages, is reported here. The distribution and apparent molecular weight of the antigen recognized by the IH1 MAb was determined in peripheral blood leukocytes, peripheral blood monocyte-derived macrophages and tissue sections of spleen, liver and skin, using Western blotting, immunocytochemistry, immunohistochemistry and flow cytometry. The IH1 MAb-recognized antigen was detected in Western blotting under non-reducing conditions spread out as a large band covering the position corresponding to the migration of molecules with molecular weights from 55 to $73 \mathrm{kDa}$. The IH1 MAb labeled blood monocytes, tissue macrophages in lymph nodes, and in the mantle zone of the spleen, and Kupffer cells in the liver. It did not react with human cells. In flow cytometric analysis, the IH1 MAb reacted with a subpopulation of monocytes. The MAb described herein may become a valuable tool for diagnosis and research on canine diseases.
\end{abstract}

\section{INTRODUCTION}

B ESIDES THEIR IMPORTANCE as companion and working domestic animals, dogs have become a useful animal model in biomedical research. Dogs are used in studies on transplantation and on infections diseases such as leishmaniasis and many diseases that also occur in human beings. For instance, dogs spontaneously develop a variety of diseases such as allergic asthma, ${ }^{(1)}$ penfigus, systemic lupus eritematosus, and congenital or acquired immunodeficiences, ${ }^{(2)}$ providing an adequate model for research.

Monocytes/macrophages are the major target cells for most intracellular pathogens. ${ }^{(2)}$ These cells also play important roles in graft rejection ${ }^{(3)}$ and in the development of the immune response in zoonosis such as leishmaniasis. ${ }^{(4)}$ Nevertheless, the panel of cell markers for the identification of different macrophage populations in dog is restricted.

Macrophages are widely distributed throughout body tissues, showing a high plasticity and constituting a heterogeneous cell population. Depending on their localization, macrophages show differences in their morphology, function and antigen expres- sion. Moreover, macrophages may be in different maturation and activation stages. ${ }^{(5)}$

Monoclonal antibodies with specificity against canine leukocytes have been reported previously. However, only a limited panel of canine cell markers are available. ${ }^{(6-10)}$ These antibodies react with many cell types, especially lymphocytes and/or granulocytes. However, antibodies that react with canine monocytes and macrophages are rare. ${ }^{(11-13)}$

The production and partial characterization of a monoclonal antibody binding to canine monocytes/macrophages but not to granulocytes and lymphocytes is reported here. Its successful uses in immunohistochemical and flow cytometric analysis are also reported.

\section{MATERIALS AND METHODS}

\section{Animals and tissues}

Two normal 24-36-month-old outbreed dogs, weighing 15 $\mathrm{kg}$, were used throughout the study. The dogs were kept separately, under standard care and feeding conditions, in the ken-

\footnotetext{
${ }^{1}$ Laboratorio de Patologia e Bio-Intervenção, Centro de Pesquisas Gonçalo Moniz, Fundação Oswaldo Cruz, Bahia, Brazil.

${ }^{2}$ Departamento de Patologia e Clínica, Escola de Medicina Veterinária Universidade Federal da Bahia, Bahia, Brazil.

${ }^{3}$ Escola Bahiana de Medicina, Fundação para Desenvolvimento da Ciência, Bahia, Brazil.
} 




FIG. 1. Western blot of canine PBMC lysates on nitrocellulose membrane, stained with the IH1 monoclonal antibody (MAb). Nitrocellulose strips were incubated with saline (1); normal mouse serum (2); isotype matched control (3), and IH1 MAb (4). The positions of molecular weight markers, stained with Comassie blue, are shown on the left.

nel of Gonçalo Moniz Research Center, Oswaldo Cruz Foundation and used as blood donors. Normal dog tissues were obtained from the Department of Pathology and Clinics, Veterinary School, Federal University of Bahia. These specimens were derived from necropsy of animals brought to the ambulatory for various reasons. Ten six-month old, female BALB/c mice, maintained under standard conditions, from the breeding stock of the Gonçalo Moniz Research Center, were used for immunization with dog antigens. All the experiments were conducted according to the Oswaldo Cruz Foundation guidelines for animal experimentation.

\section{Antigen preparation and monoclonal antibody production}

The procedure for the monoclonal antibody production is detailed elsewhere. ${ }^{(14)}$ Briefly, canine blood leukocytes were used for immunizing BALB/c mice, the splenocytes of which were fused with $\mathrm{SPO}_{2}$ myeloma cells (Sp20-Ag14), following standard procedures. ${ }^{(15)}$ Hybrid cells showing antibody activity against canine leukocytes were screened by $\operatorname{ELISA}^{(14)}$ and the antibody-producing cells were subjected to three subsequent rounds of subcloning steps, by limiting dilution, in order to obtain stable hybridomas. Culture supernatants were used in sub- sequent experiments. The isotype of the MAbs was determinated using a mouse monoclonal antibody isotyping kit (monoclonal antibody-based mouse Ig isotyping kit; B\&D PharMingen, Los Angeles, CA). The assay was performed following the protocol recommended by the manufacturer.

\section{Immunoprecipitation analysis and Western blotting}

Canine spleen cells were suspended to $5 \times 10^{6}$ cells $/ \mathrm{mL}^{-1}$ in $0.15 \mathrm{M}$ phosphate-buffered saline, $\mathrm{pH} 7.2$ (PBS), subjected to 1220 -sec sonification bursts (Sonifier 450 Brandson, USA) and incubated in a $100 \mathrm{mM} \mathrm{NaCl}, 1 \mathrm{mM}$ PMSF water solution, for $1 \mathrm{~h}$ at $4^{\circ} \mathrm{C}$. The insoluble fraction was removed by centrifugation at $500 \mathrm{~g}$ for $30 \mathrm{~min}$. The MAb was coupled to protein A-Sepharose beads (Pharmacia, Uppsala, Sweden). Onemilliliter volume of all spleen cell extracts were incubated with $100 \mu \mathrm{L}$ of protein A-Sepharose beads for $1 \mathrm{~h}$. The supernatant was then incubated with $100 \mu \mathrm{L}$ of MAb-coated Sepharose beads for $1 \mathrm{~h}$ at $4{ }^{\circ} \mathrm{C}$, with continuous rotation. The beads were washed with PBS containing $0.05 \%$ of Tween 20 (PBS-T20), resuspended with sodium dodecyl sulfate-polyacrylamide gel electrophoresis (SDS-PAGE) sample buffer (62.5 mM Tris$\mathrm{HCl}, 2 \% \mathrm{w} / \mathrm{v} \mathrm{SDS}$ in $10 \% \mathrm{v} / \mathrm{v}$ glycerol/water) and removed by centrifugation. The protein A-Sepharose immunoprecipitated 


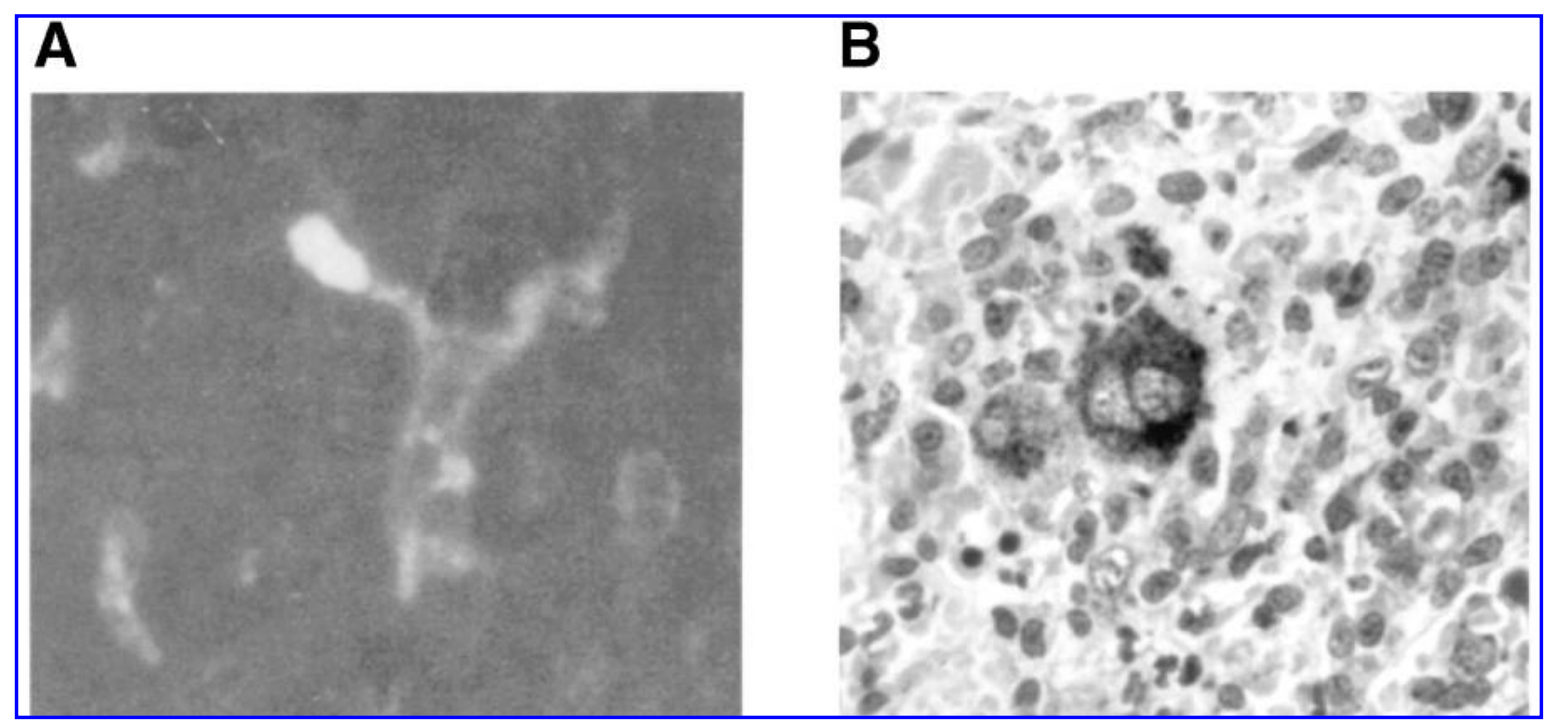

FIG. 2. Immunofluorescence of canine liver and immunoperoxidase staining of canine spleen by the IH1 monoclonal antibody (MAb). In liver, the MAb stained Kupffer cells (A), and in the spleen the IH1 MAb stained megakaryocytes (B). Original magnification, $\times 400$.

antigens were run in SDS-PAGE under reducing (with 2-mercaptoethanol) and non-reducing (without 2-mercaptoethanol) conditions, as described by Harlow \& Lane. ${ }^{(15)}$ Proteins were then electrophoretically transferred to nitrocellulose membrane and incubated with the hybridoma supernatants, diluted $1: 2$, in PBS-T20 containing 5\% skimmed milk powder (w/v; PBS-T20milk), followed by successive incubations with peroxidase-conjugated sheep anti-mouse immunoglobulin polyclonal antibodies (Sigma Chemical Co., St. Louis, MO) and a mixture of 3,3'-diaminobenzidine (DAB, Sigma Chemical Co.) and $\mathrm{H}_{2} \mathrm{O}_{2}$ in PBS. A normal mouse serum dilution containing approximately $25 \mu \mathrm{g}$ of immunoglobulin per mL of PBS-T20-milk was used as negative control.

\section{Indirect immunofluorescence}

Immunofluorescence reactions were carried out on Tween 20-permeabilized or non-permeabilized canine and human PBMC. Cryostat sections (6-8 $\mu \mathrm{m}$ in thickness) of normal canine lymph node, spleen, liver, skin, and kidney were also tested by indirect immunofluorescence. PBMC or tissue sections were air-dried and fixed in alcohol for $5 \mathrm{~min}$ at room temperature (RT). After three washes in PBS, the tissue sections and PBMC were incubated for $30 \mathrm{~min}$ at $37^{\circ} \mathrm{C}$ with hybridoma supernatants diluted 1:2 in PBS or PBS-T20-milk. The detergent was used for membrane permeabilization to guarantee the access of the MAb to cytoplasm epitopes. Irrelevant antibody, diluent and normal mouse serum (diluted 1:500) were used as negative controls. The slides were then washed three times in PBS and incubated for $30 \mathrm{~min}$ with fluorescein isothiocyanate (FITC)conjugated sheep IgG anti-mouse immunoglobulins (Sigma Chemical Co.) diluted 1:200 in 1\% Evans Blue in PBS. After washing three times with PBS for $10 \mathrm{~min}$, the slides were mounted with glycerol buffer and examined by UV microscopy.

\section{Immunohistochemical staining}

Samples from spleen and lymph nodes were collected from a healthy mongrel dog that had been sacrificed with an over- dose of phenobarbital. The same cryostat sections of canine tissues used in immunofluorescence were also tested in immunohistochemical assay. A normal lymph node was also collected from a mouse killed by excess anesthesia. The tissues were placed in neutral buffered $10 \%$ formalin for $12 \mathrm{~h}$, and embedded in paraffin wax. Serial $5-8-\mu$ m-thick sections were cut, placed on poly-L-lysine (Sigma Chemical Co.)-coated slides, and allowed to dry at room temperature. The slides were dewaxed in xylene, rehydrated through graded alcohols to distilled water and subjected to a heat-mediated antigen retrieval treatment, following the protocol described by Shi et al. ${ }^{(16)}$ Briefly, the slides were placed into a plastic bag filled with 0.01 $\mathrm{M}$ sodium citrate buffer, $\mathrm{pH}$ 6.0, and heated in a steamer for $30 \mathrm{~min}$. Once cooled, the heat-treated slides were washed twice for 5 min each in PBS. Before staining, endogenous peroxidase was inhibited by incubation with $\mathrm{H}_{2} \mathrm{O}_{2}$ and sodium azide in PBS. ${ }^{(16)}$ Non-specific binding was blocked by pre-incubation of the slides with $10 \%$ normal rabbit serum and bovine serum albumin in PBS. The hybridoma supernatants were then applied onto the slides and left overnight at $4{ }^{\circ} \mathrm{C}$. After two washes of 5 min with PBS, the slides were incubated with a 1:600 dilution of a biotin-rabbit anti-mouse immunoglobulin conjugate (DAKO, Capinteria, CA) for $45 \mathrm{~min}$ at $37^{\circ} \mathrm{C}$. The sections were then incubated for 30 min with a 1:500 dilution of a streptoavidin-peroxidase conjugate (Pierce, Chemical Co., Rockford, IL). After two washes with PBS, the peroxidase activity was developed with a mixture of $25 \mu \mathrm{g} \cdot \mathrm{mL}^{-1}$ of 3,3-diamine-benzidine (Sigma Chemical Co.) and $0.05 \% \mathrm{H}_{2} \mathrm{O}_{2}$ in PBS for 2 min. The slides were then washed in distilled water, counterstained with hematoxylin, gradually dehydrated with alcohol and mounted in Canadian balsam (Riedel de Haen AG, Hannover, Germany). Either, the control section lacked primary antibody, or it was replaced by an irrelevant isotype-matched MAb.

\section{In vitro macrophage differentiation}

Canine PBMC were adjusted to the concentration of $5 \times$ $10^{6} / \mathrm{mL}$ in RPMI medium supplemented with $20 \%$ heat-inacti- 


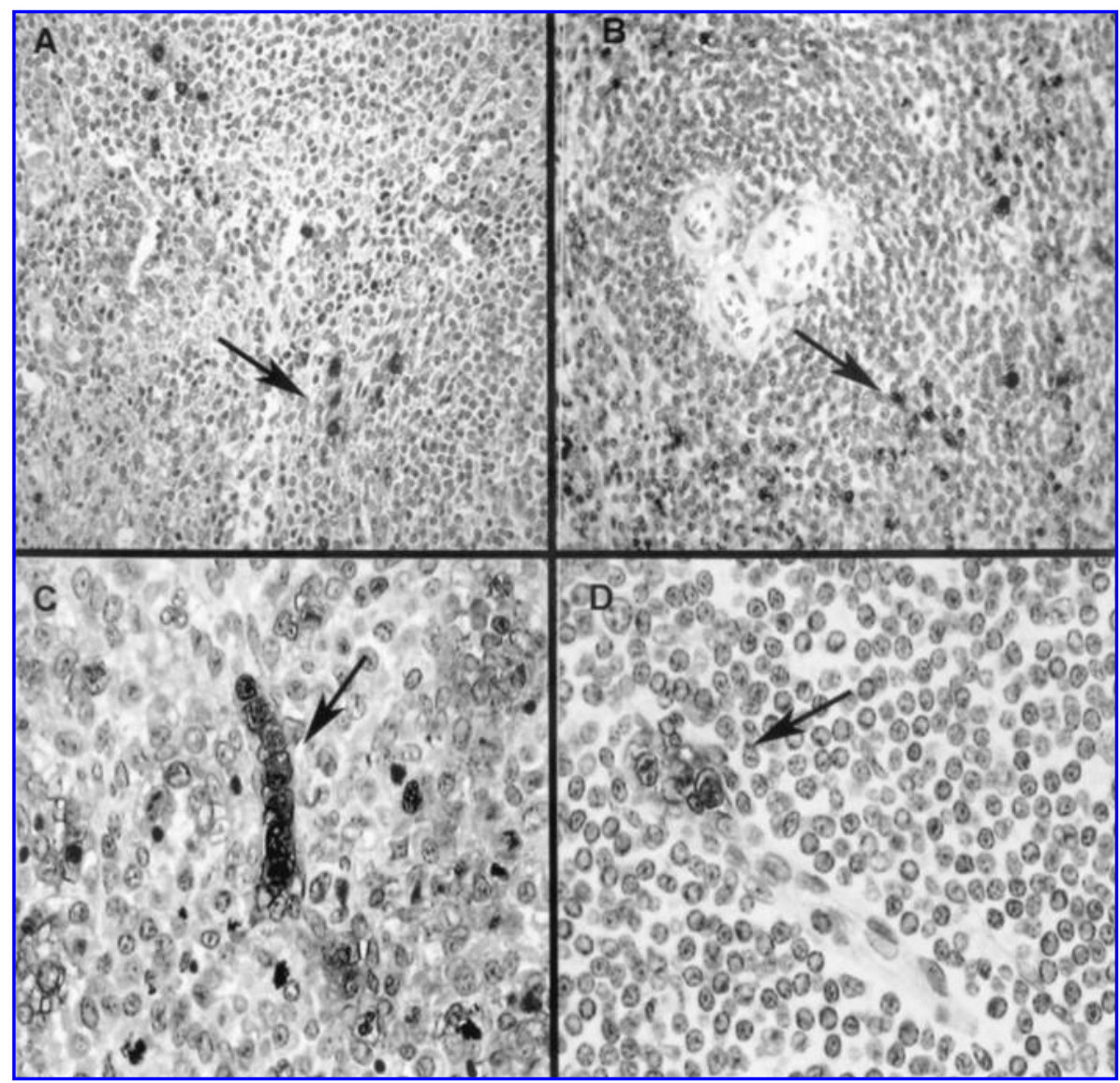

FIG. 3. Immunoperoxidase staining of spleen $(\mathbf{A}, \mathbf{C})$ and lymph node $(\mathbf{B}, \mathbf{D})$ by the IH1 MAb in formalin-fixed, paraffin-embedded sections. In the spleen, the IH1 MAb stained macrophages in the mantle zone and some scattered macrophages in the red pulp, as well as megakaryocytes. It did not mark macrophages in the lymphoid areas. In lymph nodes, the IH1 MAb labeled macrophages in the marginal sinus, some dispersed macrophages in the paracortical area, and in the medullar cords. The arrows indicate macrophages $(A, B)$, and monocytes $(C, D)$. Sections were counterstained with hematoxylin. Original magnification, $\times 200$ $(\mathrm{A}, \mathrm{B}), \times 400(\mathrm{C}, \mathrm{D})$.

vated fetal bovine serum, and a cell suspension was delivered into flat-bottomed chamber slide or culture dishes (Nunc, Naperville, IL), for $24 \mathrm{~h}$, and carefully washed. The adsorbed cells were further incubated for five to ten days. The monocytederived macrophages adhered to the chamber slide bottoms, were used in indirect immunofluorescence tests using the MAb and control immunoglobulin as described above. To perform cytometric analysis, the adherent cells were detached from the Petri dish with cell scrapers, washed three times with washing solution and the expression of surface antigen were analyzed by cell cytometry, as described below. ${ }^{(3)}$

\section{Flow cytometry}

Ten milliliters of blood, collected by venipuncture of the cephalic vein, was incubated at room temperature, for $15 \mathrm{~min}$, with $40 \mathrm{~mL}$ of a hemolytic solution $\left(8.26 \mathrm{~g}\right.$ of $\mathrm{NH}_{4} \mathrm{Cl}, 1 \mathrm{~g}$ of $\mathrm{KHCO}_{3}$, and $0.037 \mathrm{~g}$ of $\mathrm{Na}_{4}$ EDTA per liter of distilled water). The suspension was centrifuged at $700 \mathrm{~g}$ for $1 \mathrm{~min}$ and the supernatant removed. The cells were washed three times with washing solution $\left(0.1 \% \mathrm{NaN}_{3}\right.$ and $5 \% \mathrm{BSA}$ in PBS) and adjusted to the concentration of $2 \times 10^{7} / \mathrm{mL}$. $100 \mu \mathrm{L}$ of the cell suspension was delivered into wells of 96-well microplate (Nunc, Naperville,
IL), incubated with a 1:2 dilution of the hybridoma supernatant for $20 \mathrm{~min}$ at $4{ }^{\circ} \mathrm{C}$, and washed three times. FITC-conjugated sheep anti-mouse immunoglobulin (Sigma Chemical Co.), diluted 1:200 in PBS, was added to the sediment and incubated for $20 \mathrm{~min}$ at $4{ }^{\circ} \mathrm{C}$. The plate was centrifuged and cells were resuspended in $500 \mu \mathrm{L}$ of washing solution prior to analysis in a FACScan flow cytometer (Becton Dickinson, Mountain View, CA). Negative control samples were stained with the secondary antibody only. This procedure, including the buffers for indirect immunofluorescence labeling, was recommended by the Canine Leukocyte Antigen Workshop (CLAW). ${ }^{(17)}$

For two-color analysis, the cells were incubated with MAbs against canine CD4 (rat anti-canine CD4 monoclonal antibody, Serotec, England), and CD8 (rat anti-canine CD8 monoclonal antibody, Serotec, Oxford, England). Free binding sites were blocked with $5 \%$ heat-inactivated normal canine serum.

Biotinylation of the MAbs was carried out using NHS-biotin (Vector Laboratories, Burlingame, CA) according to the protocol suggested by the supplier. The reactions with the IH1, antiCD4, and anti-CD8 MAbs were detected using FITC-conjugated sheep anti-rat immunoglobulin. Reactivity with the biotinylated MAbs was detected using B-phycoerythrin-conjugated streptavidin (Sigma Chemical Co.). 


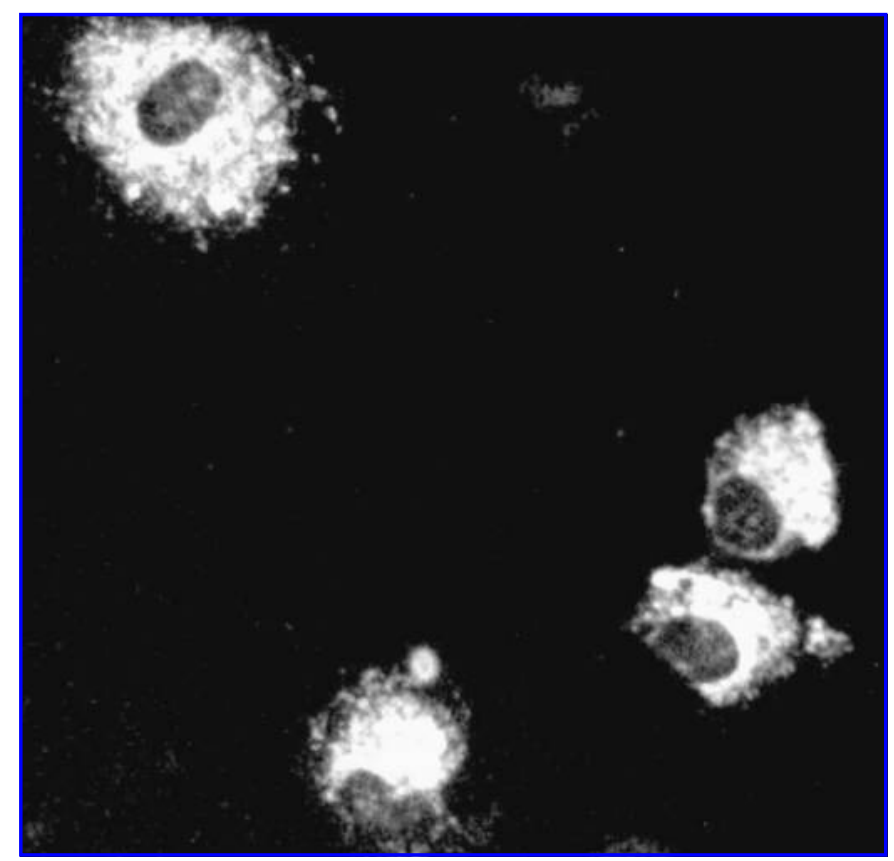

FIG. 4. Canine peripheral blood monocyte-derived macrophages, mature macrophages in cell cultures stained by indirect immunofluorescence. Large adherent cells with elongated projections stained by the IH1 MAb. Morphological appearance on day 8. Original magnification, $\times 400$.

\section{RESULTS}

\section{Molecular weight of the antigen recognized by IHI MAb}

Under non-reducing conditions, the IH1 MAb recognized a broad protein band spread out between the position corresponding to molecules with molecular weights of 55 and 73 $\mathrm{kDa}$, in Western blotting using canine leukocyte PBMC (Fig. 1). Under reducing conditions, no positive bands were identified by the IH1.

\section{Antigen distribution on peripheral blood and lymphoid tissue cells by immunofluorescence and immunohistochemistry}

The tissue distribution of the antigens recognized by the IH1 MAb was analyzed by immunofluorescence and immunohistochemical staining on different canine tissues.

Monocytes were the majority of cells stained by IH1 MAb when a single cell suspension of canine PBMC was tested by immunofluorescence. The staining pattern was diffuse and homogeneous, in the presence or absence of membrane permeabilization with Tween-20.

The staining pattern of the IH1 MAb on canine tissue sections was similar with immunohistochemistry and immunofluorescence. The MAb also stained cells on formalin-fixed, paraffin embedded tissue sections.

The IH1 MAb identified a cell population of the mononuclear phagocytic system in the spleen and lymph nodes. In the spleen it stained macrophages in the mantle zone and some scattered macrophages in the red pulp, as well as megakaryocytes (Fig. 2). It did not stain macrophages in the lymphoid areas. In lymph nodes, the IH1 MAb labeled macrophages in the marginal sinus, some dispersed macrophages in the paracortical area, and in the medullar cords (Fig. 3). In the liver, the IH1 MAb detected cells scattered on the parenchyma. These cells showed the morphology of Kupffer cells (Fig. 2).

The IH1 antibody also stained, by indirect immunofluorescence, peripheral blood monocyte-derived macrophages in cell cultures in chamber slides. These cells, approximately on day 8 of culture, became large, round or spindle-shaped adherent cells with long dendritic projections (Fig. 4). It did not stain, by indirect immunofluorescence, human PBMC.

\section{Cell population in peripheral blood expressing IHI antigen}

Canine cell populations from whole blood were previously identified by size (FSC) and granularity (SSC), using flow cytometric analysis, as granulocytes, monocytes and lymphocytes. The IH1 MAb was able to identify monocytic cell populations, but did not show any reactivity with granulocytes or lymphocytes. The relative percentage of marked monocytes by $\mathrm{IH} 1$ MAb was $86.3 \%$ (Fig. 5).

Double labeling of canine blood leukocytes was performed in order to access the reactivity of the IH1 MAb against CD4 ${ }^{+}$ and $\mathrm{CD}^{+}$cells. The IH1 MAb reacted with $49.9 \%$ of $\mathrm{CD}^{+}$ and $38.8 \%$ of $\mathrm{CD}^{+}$monocytes (Fig. 6).

\section{DISCUSSION}

The IH1 MAb, described herein, recognizes some populations of monocytes/macrophages. Under non-reducing condi- 

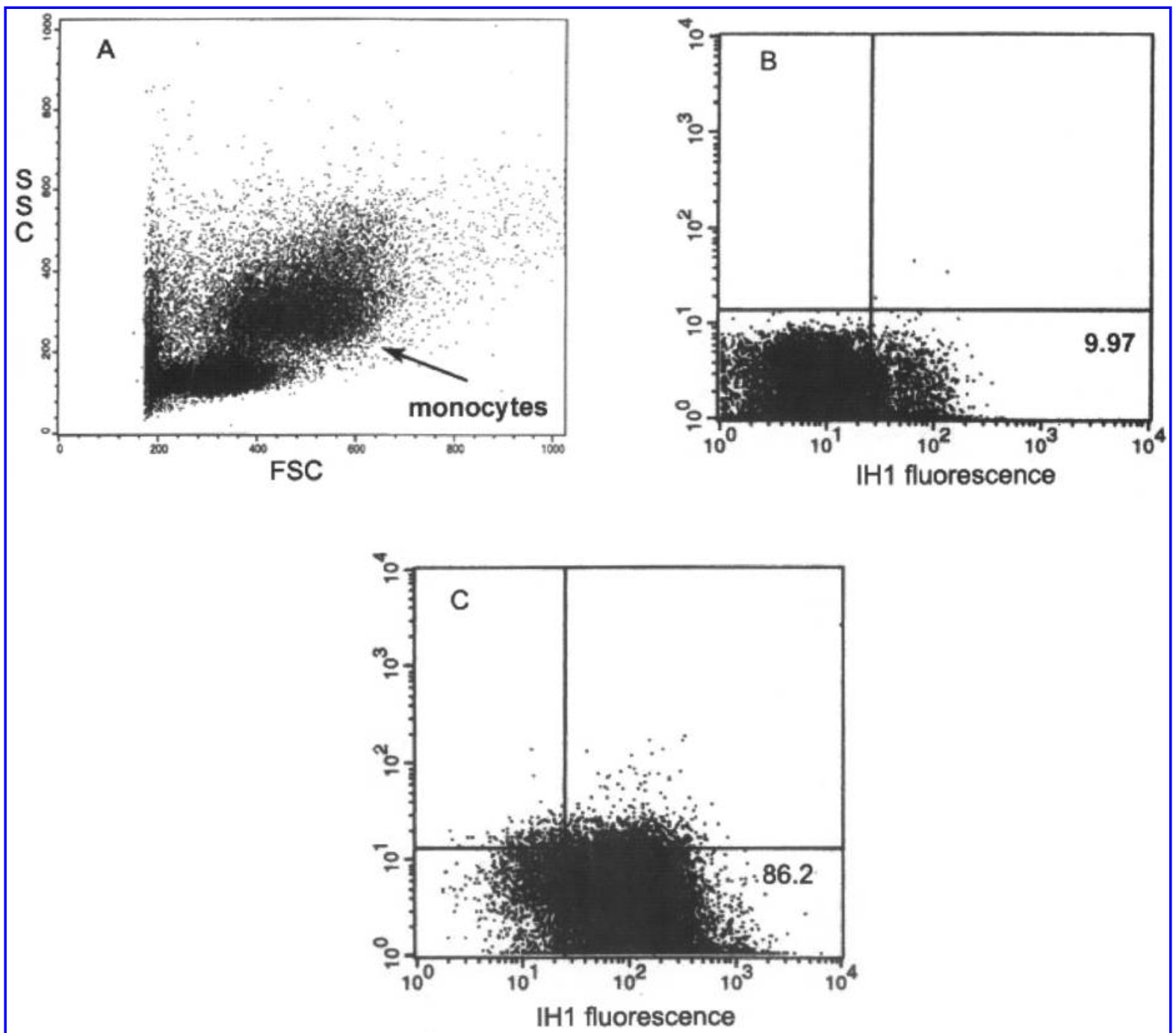

FIG. 5. Flow cytometry analysis of canine whole-blood cells. Light forward-scatter (FSC) and side-scatter (SSC) (A); the IH1 MAb was able to identify cell populations of the peripheral blood cells but did not show any reactivity with granulocytes or lymphocytes $(\mathbf{B})$; relative percentage of marked monocytes by IH1 MAb $(\mathbf{C})$. Numbers indicate the percentage of cells within the respective regions.

tions, the MAb recognized a broad protein band spread out between 55 and $73 \mathrm{kDa}$, in Western blotting using canine leukocyte lisate. This characterizes the MAb as an antibody recognizing conformational epitopes of a monocyte/macrophage antigen.

The IH1 MAb stained monocytes in PBMC, peripheral blood monocyte-derived macrophages and mature macrophages in cell culture, by indirect immunofluorescence, recognizing, therefore, an epitope expressed at early and late stages of macrophage differentiation.

A considerable number of monoclonal antibodies, which recognize human monocytes/macrophages, have been reported. However, most of them were cross-reactive with other cells. For example, anti-CD11, CD13, CD16, CD35, CD68, CD87, CD89, CD93, CD101, CD121, CD123, CD131, and anti-CD162 were found also to react with granulocytes. Anti-CD31, CD32, CD36, CD40, CD49, CD63, CD74, CD80, CD85, CD86, CD119, and anti-CD121 also labeled platelets and B cells. Oth- ers, such as anti-CD49 and CD69, labeled T cells ( $7^{\text {Th }}$ Human Leukocyte Typing Workshop). ${ }^{(18)}$

The IH1 MAb, however, recognized only cells of the monocyte/macrophage lineage and megakaryocytes: reacted with macrophages in the marginal sinus and with some dispersed macrophages in the paracortical area and in the medullar cords in the lymph node. It stained macrophages in the mantle zone and some scattered macrophages in the red pulp, as well as megakaryocytes in the spleen, and liver Kupffer cells. It did not, however, stain all monocytes: in cytometric studies, the relative percentage of monocytes stained by IH1 MAb was $86.3 \%$. Granulocytes and lymphocytes remained negative. With flow cytometric analysis of whole blood preparations it is possible to completely discriminate canine monocytes and lymphocytes by FSC (forward-scatter, cell size) and SSC (side-scatter, cell granularity). In the monocyte subset, the IH1 MAb reacted with $49.9 \%$ of $\mathrm{CD}^{+}$and $38.8 \%$ of $\mathrm{CD}^{+}$monocytes.

The IH1 antibody is comparable to the antibodies that de- 


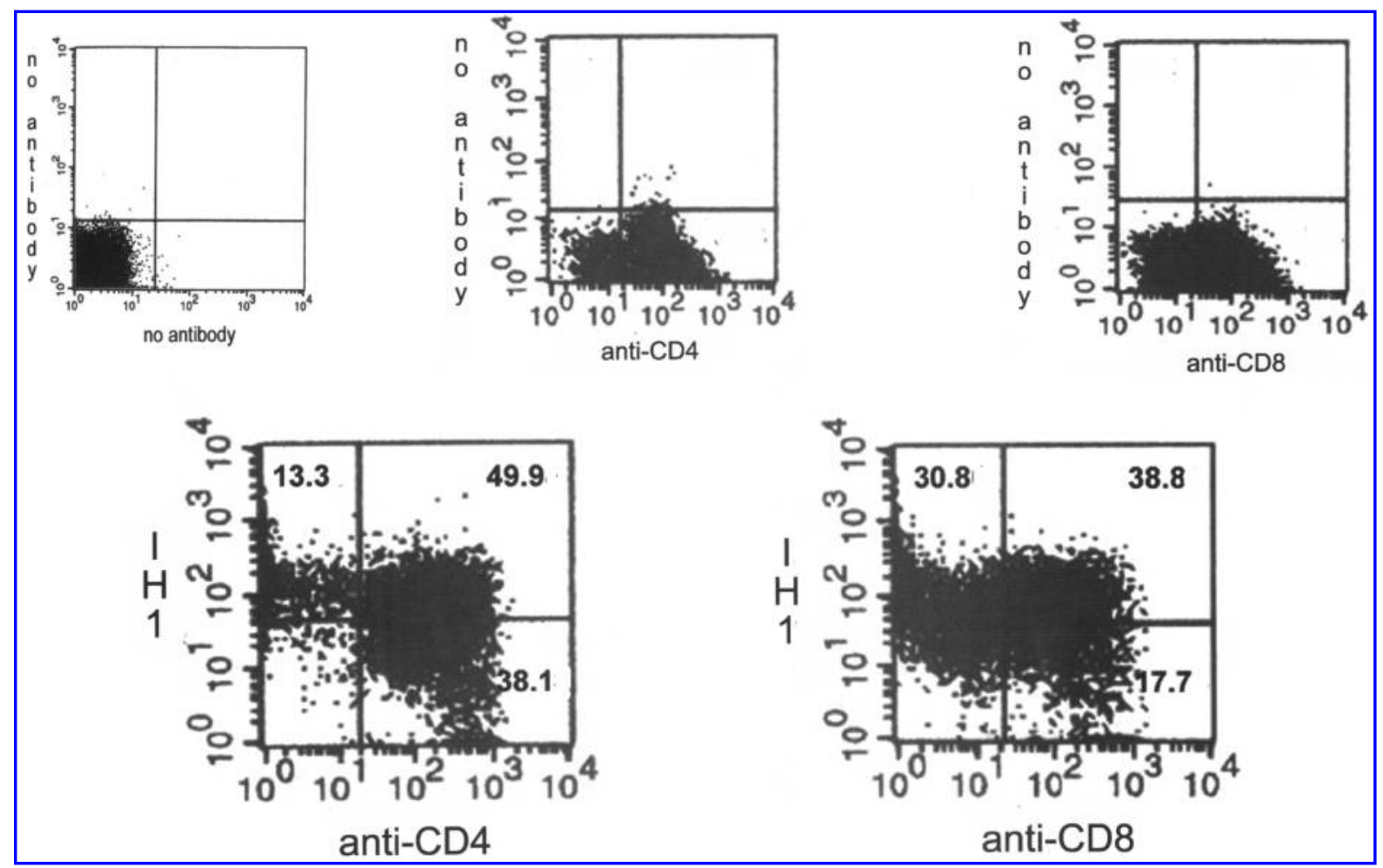

FIG. 6. Two-color flow cytometric analysis of canine whole-blood cells stained with the IH1 monoclonal antibody and antiCD4 or anti-CD8 monoclonal antibodies. Numbers indicate the percentage of cells within the respective regions.

tected the human CD14 and CD163 antigens, concerning their cell distribution. ${ }^{(19,20)}$

The CD163 is a membrane glycoprotein with molecular weight ranging from 110 to $130 \mathrm{kDa}$, expressed on human monocytes and macrophages, in the intermediate and late phase of inflammation. Although there are similarities in the pattern of cell type and tissue distribution of the human monoclonal antibody-identified CD163, this molecule is described with a molecular weight of $110-130 \mathrm{kDa}^{(20)}$ On the other hand, the IH1 MAb identified antigens with quite a different range of molecular weight, from 55 to $73 \mathrm{kDa}$, even though its staining pattern follows the same one described by the anti-human CD163.

A major common molecule in cells of the monocyte/macrophage lineage is the CD14 antigen, the receptor for LPS, with molecular weight of $55 \mathrm{kDa}$, and a predominant distribution on human monocytes and a variety of types of tissue macrophages. ${ }^{(19)}$ A possible reactivity of the IH1 antibody with this molecule has to be investigated in further studies.

The IH1 MAb did not cross-react with human PBMC, despite some authors report that MAbs developed against human leukocytes reacted with epitopes on canine cells at a relatively high proportion, suggesting that the recognized antigens may be conserved among philogenetically distant animals. ${ }^{6,7,21-23)}$

Among the different techniques used to identify macrophages in tissue samples, immunohistochemical labeling with monoclonal antibodies is one of the most reliable.

The routine processing of tissues for histopathological examination usually involves an aldehyde fixation step and results in a loss or decrease of antigenicity because the crosslinking of reactive sites on proteins makes certain epitopes inaccessible to antibodies. The formalin-fixed, paraffin-embedded tissues, however, have the advantage over frozen sections of easier handling and better preservation of tissue samples, improving morphologic resolution. ${ }^{(24)}$

Many monoclonal anti-leukocyte antibodies are only useful for staining frozen tissue sections with its inherent poor morphology definition, and are not readily adapted to formaldehyde-fixed and paraffin-embedded tissue. ${ }^{(25-27)}$ Conventional processing of the tissue was sufficient for optimal immunohistochemical detection of IH1-antigen expressing cells. The staining pattern of the MAb was similar comparing the two techniques, immunohistochemistry and immunofluorescence, but morphologic resolution was better on formalin-fixed, paraffinembedded tissue. Hence, the IH1 MAb constitutes a useful tool for detection of monocytes/macrophages in routinely processed paraffin-embedded tissue sections. It could allow new and retrospective studies using material commonly processed for histopathological diagnosis.

The canine immune system is of veterinary and general biological interest. The development of monoclonal antibodies against canine cluster differentiation (caCD) antigens has facilitated its characterization. Some monoclonal antibodies against canine myeloid antigens have been reported, but MAbs that exhibit an exclusive reactivity with canine monocytes/macrophages are rare.

A clearest identity of the reactivity of the MAb described herein with any antibody already reported could not be found. The assignment of an anti-CD specificity to this MAb by the identification of the recognized antigens through their amino acid sequencing is a necessary future. The IH1 MAb was shown 
to be useful for detection of monocytes/macrophages in routinely processed paraffin-embedded tissue sections. Its application in immunohistochemical and flow cytometric analysis may provide valuable information on the role of macrophages in the pathogenesis of different diseases, in which these cells may be involved.

\section{REFERENCES}

1. Eber E, Uhlig T, and McMenanin C: Lefluomide, a novel immunomodulating agent prevents the development of allergic sensitization in an animal model of allergic asthma. Clin Exp Allergy 1998;28:376-384.

2. Pedersen NC: A review of immunologic diseases of the dog. Vet Immunol Immunopathol 1999;69:254-342.

3. Yoshida H, Momoi Y, Taga N, Ide K, Yamazoe K, Iwasaki T, and Kudo T: Generation of canine dendritic cells from peripheral blood mononuclear cells. J Vet Med Sci 2003;65:663-669.

4. Pinelli E, Killick-Kendrick R, Wagenaar J, Bernadina W, del Real G, and Ruitenberg J: Cellular and humoral responses in dogs experimentally and naturally infected with $L$. infantun. Infect Immun 1994;26:229-235.

5. Papadimitriou JM, and Ashman RB: Macrophages: current views on their differentiation, struture and function. Ultrastruct Pathol 1989;13:343-372.

6. Galkowska H, Waldemar LO, and Wojewodska U: Reactivity of antibodies directed against human antigens with surface markers on canine leukocytes. Vet Immunol Immunopathol 1996;53:329 334.

7. Willians DL: Studies of canine leucocyte antigens: a significant advance in canine immunology. Vet J 1997;153:31-39.

8. Borrebaeck CAK: Antibodies in diagnostics-from immunoassay to protein chips. Immunol Today 2000;21:379-382.

9. Herzenberg LA, DeRosa SC, and Herzenberg LA: Monoclonal antibodies and the FACS: complementary tools for immunobiology and medicine. Immunol Today 2000;21:383-390.

10. Wunschmann A, Kremmer E, and Baumgartner W: Phenotypical characterization of $\mathrm{T}$ and $\mathrm{B}$ cell areas in lymphoid tissues of dogs with spontaneous distemper. Vet Immunol Immunopathol 2000; 73:83-98

11. Danilenko DM, Moore PF, and Rossitto PV: Canine leukocyte cell adhesion molecules (LeuCAMs): characterization of the CD11/ CD18 family. Tissue Antigens 1992;40:14-21.

12. Danilenko DM, Rossitto PV, Van der Vieren M, Trong HL, McDonough SP, Affolter VK, and Moore PF: A novel canine leukointegrin, $\alpha_{\mathrm{d}} \beta_{2}$, is expressed by specific macrophages subpopulation in tissue and a minor $\mathrm{CD} 8^{+}$lymphocyte subpopulation in peripheral blood. J Immunol 1995;155:33-44.

13. Yamate J, Yoshida H, Tsukamoto Y, Ide M, Kuwamura M, Ohashi F, Myamoto T, Kotani T, Sakuma S, and Takeya M: Distribution of cells immunopositive for AM-3K, a novel monoclonal antibody recognizing human macrophages, in normal and diseased tissues of dogs, cats, horses, cattle, pigs and rabbits. Vet Pathol 2000;37:168-176.

14. Aguiar PHP, Santos RRR, Lima CA, Gomes HRS, Larangeira DF, Santos PM, Barrouin-Melo SM, dos-Santos WLC, and Pontes-deCarvalho L: Production of monoclonal antibodies against canine leukocytes. Hybridoma Hybridomics 2004;23:127-132.
15. Harlow E, and Lane D: Antibodies: A Laboratory Manual. Cold Spring Harbor Laboratory Press, Cold Spring Harbor, NY, 1988.

16. Shi SR, Kei ME, and Kalra KL: Antigen retrieval in formalin fixed, paraffin-embedded tissues: an enhancement method for immunohistochemical staining based on microwave oven heating of tissue sections. J Histochem Cytochem 1991;39:741.

17. Cobbold S, and Metcalfe SU: Monoclonal antibodies that define canine homologues of human CD antigens. Summary of the First International Canine Leukocyte Antigen Workshop (CLAW). Tissue Antigens 1994;43:137-154.

18. Mason D, André P, Bensussan A, et al: Reference: CD antigens 2002. J Immunol 2002;168:2083-2086.

19. Ziegler-Heitbrock HWL, and Ulevitch RJ: CD14: cell surface receptor and differentiation marker. Immunol Today 1993;14:121125.

20. Hogger P, Jens Dreier J, Droste A, Buck F, and Sorg C: Identification of the integral membrane protein RM3/1 on human monocytes as a glucocorticoid-inducible member of the scavenger receptor cysteine-rich family (CD163). J Immunol 1998;161:18831890.

21. Jacobsen CN, Aasted E, Broe MK, and Petersen JL: Reactivities of 20 anti-human monoclonal antibodies with leucocytes from different animal species. Vet Immunol Immunopathol 1996;39: 461-466.

22. Brodersen R, Bijlsma F, Gori K, et al. Analysis of the immunological cross-reactivities of 213 well characterized monoclonal antibodies with specificities against various leucocyte surface antigens of human and 11 animal species. Vet Immunol Immunopathol 1998;64:1-13.

23. Berndt A, Heller M, Methner U, Kosmehl H, and Muller G: Monoclonal antibodies against porcine macrophages. Vet Immunol Immunopathol 2000;74:163-177.

24. Domenech N, Rodrigues-Carreno P, Filgueira P, Alvarez B, Chamorro S, and Dominguez J: Identification of porcine macrophages with monoclonal antibodies in formalin-fixed, paraffin-embedded tissues. Vet Immunol Immunopathol 2003;94:77-81.

25. Gendelman HE, Moench TR, Narayan O, and Griffin DE: Selection of a fixative for identifying $\mathrm{T}$ cell subsets, B cells, and macrophages in paraffin-embedded mouse spleen. $\mathrm{J}$ Immunol Methods 1983;65:137-145.

26. Collings LA, Poulter LW, and Janossy G: The demonstration of cell surface antigens on T cells, B cells and accessory cells in paraffin embedded humans tissues. J Immunol Methods 1984;31:227239.

27. Holgate CS, Jackson P, Pollard K, Lunny D, and Bird CC: Effect fixation on $\mathrm{T}$ and B lymphocyte surface membrane antigen demonstration in paraffin processed tissue. J Pathol 1986;149:293-300.

Address reprint requests to:

Paulo Henrique Palis Aguiar, D.V.M., M.S. Centro de Pesquisas Gonçalo Moniz

FIOCRUZ

Av Waldemar Falcão n.121 Brotas, Salvador

Bahia, Brazil, 40295-001

E-mail: phpa@ufba.br

Received for publication May 4, 2004. Accepted for publication May 17, 2004. 
This article has been cited by:

1. Edilberto Postól, André Meyer, Fabíola Cardillo, Raquel de Alencar, Daniel Pessina, Jorge Nihei, Mário Mariano, José Mengel. 2008. Long-term administration of IgG2a anti-NK1.1 monoclonal antibody ameliorates lupus-like disease in NZB/W mice in spite of an early worsening induced by an IgG2a-dependent BAFF/BLyS production. Immunology 125:2, 184-196. [CrossRef] 